This document was prepared in conjunction with work accomplished under Contract No.

DE-AC09-76SR00001 with the U.S. Department of Energy.

\title{
DISCLAIMER
}

This report was prepared as an account of work sponsored by an agency of the United States Government. Neither the United States Government nor any agency thereof, nor any of their employees, makes any warranty, express or implied, or assumes any legal liability or responsibility for the accuracy, completeness, or usefulness of any information, apparatus, product or process disclosed, or represents that its use would not infringe privately owned rights. Reference herein to any specific commercial product, process or service by trade name, trademark, manufacturer, or otherwise does not necessarily constitute or imply its endorsement, recommendation, or favoring by the United States Government or any agency

thereof. The views and opinions of authors expressed herein do not necessarily state or reflect those of the United States Government or any agency thereof.

This report has been reproduced directly from the best available copy.

Available for sale to the public, in paper, from: U.S. Department of Commerce, National Technical Information Service, 5285 Port Royal Road, Springfield, VA 22161, phone: (800)

553-6847, fax: (703) 605-6900, email: orders@ntis.fedworld.gov online ordering: http://www.ntis.gov/ordering.htm

Available electronically at http://www.doe.gov/bridge

Available for a processing fee to U.S. Department of Energy and its contractors, in paper, from: U.S. Department of Energy, Office of Scientific and Technical Information, P.O. Box 62, Oak Ridge, TN 37831-0062, phone: (865 ) 576-8401, fax: (865) 576-5728, email: reports@ adonis.osti.gov 


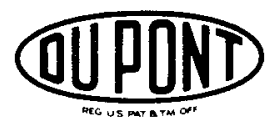

E. I. du Pont de Nemours \& Company INCORPORATED

SAVANNAH RIVER LABORATORY

AIKEN, SOUTH CAROLINA 29808-0001

(TWX: 810-771-2670, TEL: 803-725-6211, WU: AUGUSTA, GA.)

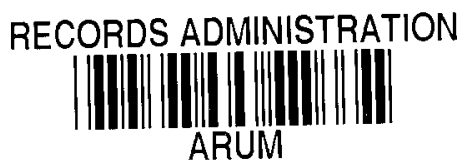

J. T. GRANAGHAN, PLANT MANAGER

SAVANNAH RIVER PLANT

ATTENTION: W. B. BOORE, 703-H
DPST-86-333-TL

LP No. 10332

CC: J.N.Beatty, 703-H

H.D.Martin, wCC-II

Wilmington, Del.

G.T.Wright (3),703-H

G.M.Johnson (3), 703-H

R.K.Ryland, RDO, Charlotte

J.K.Okeson, 773-A

W.R.Stevens, III, 773-A

BCS File, 773-A

SRL Records (4), 773-A

March 31, 1986

\section{MERCURY VOIATIIITY IN THE PRESENCE OF REDUCING AGENTS}

The attached document describes experimental evidence for the calculations reported in DPST-85-974, "Calculations of $\mathrm{Hg}, \mathrm{NH}_{3}$, and Cs-137 in the F/H Effluent Treatment Facility". These experiments show that in the $\mathrm{F} / \mathrm{H}$ Effluent Treatment Facility evaporator feed stream there will be chemical species capable of reducing mercuric ion to mercury metal. Once such reduction takes place the mercury will distill out of the evaporator.

It is our opinion that this event will take place some times during the actual operation of the Facility. The amount of mercury present in the evaporator overheads may be minimized by evaporator design. However, given the known behavior of mercury, once the Facility has operated for a time, process equipment will be "cured" with mercury. At that point we believe that the overheads from this step of the process will routinely show concentrations of at least $20 \mathrm{ppb}$, the solubility of $\mathrm{Hg}$ in water at $30^{\circ} \mathrm{C}$. Our experiments indicate that the possiblity for supersaturation exists giving rise to higher concentrations, as high a $600 \mathrm{ppb}$.

We recommend that you determine whether these concentrations will be acceptable. If not, we will explore alternatives to resolve the issue.

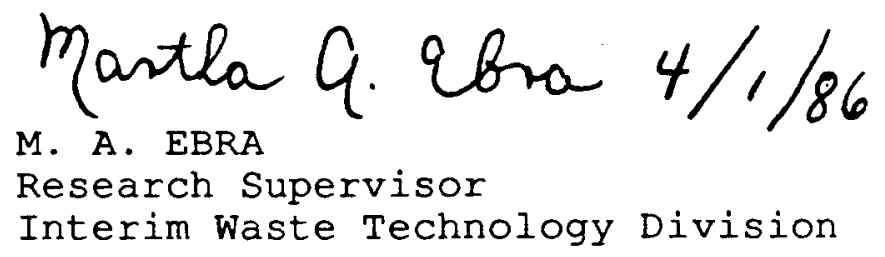




\section{F/H ETF; evaporator overheads; bisulfite mercury; ammonia; reduction}

DPST-86-333

TECHNICAL DIVISION

SAVANNAH RIVER LABORATORY

TO: M. A. EBRA

FROM: J. P. BIBLER $\mathscr{P B}$
CC: J.N.Beatty, 703-H

H.D.Martin, WCC-II

Wilmington, Del.

G.T.Wright (3),703-H

G.M.Johnson (3),703-H

D.F.Brown, 703-H

M.A.Hayes, 703-H

R.K.Ryland, RDO, Charlotte

J.K.Okeson, 773-A

W.R.Stevens, III, 773-A

L.L.Kilpatrick, 773-A

F.L.POY, 676-T

J.L.Kessler, 676-T

BCS File, 773-A

SRL Records (4), 773-A

\section{MERCURY VOLATILITY IN THE PRESENCE OF REDUCING AGENTS}

\section{INTRODUCTION}

A recent publication ${ }^{1}$ dealt with the volatility of mercury in the F/H Effluent Treatment Facility (F/H ETF) evaporator. That document predicted that, if dissolved mercuric ion should be reduced by some other substance in the evaporator feed, all of the mercury metal generated by the reduction will be volatilized into the overheads. Based on thermodynamic calculations, two chemical species that could reduce mercury, sodium bisulfite and ammonia, will be present. This document describes a laboratory study designed to determine whether mercury is, in fact, reduced by bisulfite ion and ammonia and, if so, whether the reduced mercury is volatilized at the boiling point of water. 
M. A. EBRA

DPST $-86-333$

March 13, 1986

\section{SUMMARY}

Solutions containing mercuric nitrate and various chemical reducing agents at different concentrations were distilled to reduce the volume of the solution by a factor of ten, the volume reduction factor that will be standard in the F/H ETF evaporator. The distillate and concentrate were analyzed for mercury content to determine how much mercury had been carried over into the distillate. The primary conclusions resulting from this study are that both bisulfite ion and ammonia are capable of reducing mercury in solution and that, when reduced, the mercury will all be volatilized and carried into the distillate.

\section{THERMODYNAMIC CONSIDERATIONS}

A consideration of components in feed to the F/H ETF evaporator determined two substances that could potentially reduce dissolved mercuric ion to metallic mercury. The first of these is sodium bisulfite that will be used to treat the reverse osmosis membranes to prevent growth of microorganisms or to reduce residual chlorine in solution as a result of a hypochlorite treatment to kill microorganisms. 2 The reaction of bisulfite (Equation 1 ) is thermodynamically favored. 3

$$
\mathrm{H}_{2} \mathrm{SO}_{3}+\mathrm{H}_{2} \mathrm{O}+\mathrm{Hg}^{2+} \Rightarrow \mathrm{Hg}+\mathrm{SO}_{4}=+4 \mathrm{H}^{+} \quad \Delta \mathrm{G}^{\circ}=-31.5 \mathrm{kcal}
$$

Similarly, reduction by ammonia, possibly according to Equation 2, is also favored.

$$
2 \mathrm{NH}_{3}+3 \mathrm{Hg}^{2+}=2 \mathrm{~N}_{2}+3 \mathrm{Hg}+6 \mathrm{H}^{+} \quad \Delta \mathrm{G}^{\circ}=-105.4 \mathrm{kcal}
$$

Solutions containing flowsheet concentrations expected ${ }^{2}, 4$ for bisulfite ion and ammonia as well as stoichiometric excesses of each substance, relative to mercuric ion present in solution, were tested. In each case, there was evidence that some reduction had occurred.

\section{EXPERIMENTAL PROCEDURES}

A simple glass distillation apparatus, representing a single stage evaporator, was assembled as shown in Figure 1 . One hundred mililiters of solution were reduced to a volume of $10 \mathrm{~mL}$. by distillation of $90 \mathrm{~mL}$.into the collection flask. The compositions 
M. A. EBRA

of the various solutions that were tested are found in Appendix 1. Both distillate and concentrate were allowed to reach room temperature and were then analyzed for mercury content. Glassware was rinsed with $0.5 \mathrm{M} \mathrm{HNO}_{3}$ and deionized water between experiments. The rinses were analyzed for mercury content. Those concentrations varied widely and are not reported.

Experiments were also done with some of the solutions using a glass wool baffle in the neck of the distillation apparatus. The glass wool was expected to allow only vapor phase mercury to proceed to the collection flask and to prevent entrainment. Thus, the presence of $\mathrm{Hg}$ vapor was assured and the inference of reduction could thereby be made.

\section{RESULTS AND DISCUSSION}

The mercury analyses for each experiment are tabulated in Table 1. Several conclusions are in order from this data:

- The primary indication that mercury has been reduced and volatilized in this system is the disappearance of mercury from the distillation flask. In practice mercury is deposited on the walls of the distillation apparatus, as evidenced in the presence of mercury in nitric acid rinses of the glassware. This behavior contributes to the lack of material balance for mercury between the distillate and the concentrate. The condensation of mercury vapor throughout a distillation system has been observed often in steam stripping experiments performed for the Defense Waste Processing Facility project. 5

- If sufficient reducing agent is present, all of the $\mathrm{Hg}^{2+}$ will be reduced. Once reduced, it will volatilize and, in principle, be carried into the overheads to the collection vessel. Analysis of the solution in the collection vessel should not be expected to reflect all the mercury lost from the distillation vessel. The condensate solution will be limited by the solubility of metallic mercury in water; i.e. $1 \mathrm{E}-7$ moles $\mathrm{Hg} / \mathrm{liter}$ or $20 \mathrm{ppb} \mathrm{Hg}$. The analyses of the condensates in these experiments all reflect supersaturated solutions.

- Mercuric ion is reduced in solution by bisulfite ion. A stoichiometric excess of bisulfite is necessary to reduce all the mercury present. 
- Mercuric ion is reduced in solution by ammonia. This reaction is not as efficient as reduction by bisulfite ion, probably because the $\mathrm{NH}_{3}$ is constantly being distilled from the reaction vessel in the evaporation process. Bisulfite, being nonvolatile, remains in the vessel where it can continue to react with remaining $\mathrm{Hg}^{2+}$.

- Reduction of $\mathrm{Hg}^{2+}$ still occurs in the presence of excess nitrate ion. Interaction of bisulfite with nitrate to produce nitrite and bisulfate could simultaneously occur, thereby interfering with the reduction of mercuric ion in the same solution. However, flowsheet concentrations of nitrate $(0.15 \mathrm{M})$ and bisulfite resulted in the reduction of mercuric ion in these experiments (Solution \#5). All solutions tested had at least $1.0 \mathrm{E}-2 \mathrm{M} \mathrm{NO}_{3}^{-}$by virtue of the fact that the mercury standard is in $1.0 \mathrm{M} \mathrm{HNO}_{3}$.

Also, some general observations can be made:

- The presence of mercury in the distillate (and its subsequent decrease in the concentration of the distillation solution) when only deionized water and $\mathrm{Hg}\left(\mathrm{NO}_{3}\right)_{2}$ were used in the reaction vessel indicated the presence of some reducing agent in deionized water. It is suspected that reduction may occur because of small amounts of organic residue that are present from the ion exchange column used to prepare deionized water. When a strong oxidizing agent such as potassium permanganate, $\mathrm{KMnO}_{4}$, is included in the distillation vessel, reduction of mercuric ion by these organic impurities is prevented. Experimental series 1 and 2 show a slight increase in the amount of mercury volatilized from deionized water solution when $\mathrm{KMnO}_{4}$ is not present in solution.

- The distillations proceeded at a slow boiling rate to exclude entrainment as much as possible. When glass wool was used in the apparatus, only a slight decrease in the concentration of mercury found in the distillate was observed, indicating little, if any, entrainment. When permanganate was added to the distillation flask, there was no visual evidence that any of this highly colored, nonvolatile ion was carried over to the collection flask. Manganese analyses were not performed on the distillate because analytical instruments were not 
M. A. EBRA

DPST $-86-333$

March 13, 1986

functioning.

QUALITY ASSURANCE

Experimental data for this report are contained in DPSTN-4415. Solutions were prepared from reagent grade chemicals. Mercury and mercury compounds were handled according to DPSOL 158-2-4121. Mercury analyses were done by cold vapor atomic absorption using a Perkin Elmer Model 50A mercury analyzer. All mercury analyses were verified against standard solutions. 


\section{REFERENCES}

1. WALLACE, R.M., and BIBLER, J.P., "Calculations of Volatilities of $\mathrm{Hg}, \mathrm{NH}_{3}$, and $\mathrm{Cs}-137$ in the $\mathrm{F} / \mathrm{H}$ Effluent Treatment Facility Evaporator System", DPST-85-974, December 20, 1985.

2."Preliminary Report on Disinfection Requirements", to DISTRIBUTION from R. WENDEL, C.T.Main, undated.

3. Handbook of Chemistry and Physics, 60th Ed., Chemical Rubber Company Press, Boca Raton, Florida, 1980.

4. RYAN, J.P., and STIMSON, R.E., "Technical Data Summary, F/H Effluent Treatment Facility", DPSTD-84-114, December 1984 .

5. EIBLING, R.E., private communication.

6. Current Process Flowsheet, C.T.Main, February 28, 1986. 
APPENDIX 1

SOLUTION COMPOSITIONS

\section{BLANK SOLUTIONS}

1. $99 \mathrm{~mL}$ deionized water and $1.0 \mathrm{~mL} \mathrm{Hg}\left(\mathrm{NO}_{3}\right)_{2}$ standard $1000 \mathrm{ppm}$ solution. The initial $\mathrm{Hg}$ concentration is $1 \mathrm{mg} / 100 \mathrm{~mL}$.

2. $99 \mathrm{~mL}$ deionized water (minus two drops), 2 drops $5 \frac{\circ}{\mathrm{KMnO}_{4}}$, $1.0 \mathrm{~mL} \mathrm{Hg}\left(\mathrm{NO}_{3}\right)_{2}$ standard $1000 \mathrm{ppm}$ solution. The initial $\mathrm{Hg}$ concentration is $1 \mathrm{mg} / 100 \mathrm{~mL}$.

3. $100 \mathrm{~mL}$ deionized water, $0.726 \mathrm{~g} \mathrm{Hg}$ metal.

REDUCING SOLUTIONS

\section{$\mathrm{NaHSO}_{3}$}

4. $99 \mathrm{~mL} 1.21 \mathrm{E}-4 \mathrm{M} \mathrm{NaHSO}_{3}, 1.0 \mathrm{~mL} \mathrm{Hg}\left(\mathrm{NO}_{3}\right)_{2}$ standard $1000 \mathrm{ppm}$ solution. The initial $\mathrm{Hg}$ concentration is $1 \mathrm{mg} / 100 \mathrm{~mL}$.

5. $99 \mathrm{~mL} 1.21 \mathrm{E}-4 \mathrm{M} \mathrm{NaHSO}_{3}, 1.0 \mathrm{~mL} \mathrm{Hg}\left(\mathrm{NO}_{3}\right)_{2}$ standard $1000 \mathrm{ppm}$ solution, $1.27 \mathrm{~g} \mathrm{NaNO}_{3}\left(0.15 \mathrm{M} \mathrm{NaNO}_{3}\right)$. The initial $\mathrm{Hg}$ concentration is $1 \mathrm{mg} / 100 \mathrm{~mL}$.

6. $99 \mathrm{~mL} 1.21 \mathrm{E}-4 \mathrm{M} \mathrm{NaHSO}_{3}, 1.0 \mathrm{~mL} \mathrm{Hg}\left(\mathrm{NO}_{3}\right)_{2}$ standard $1000 \mathrm{ppm}$ solution. The initial $\mathrm{Hg}$ concentration is $1 \mathrm{mg} / 100 \mathrm{~mL}$. A glass wool baffle was used to eliminate entrainment.

7. $98 \mathrm{~mL} 1.21 \mathrm{E}-4 \mathrm{M} \mathrm{NaHSO}_{3}, 2.0 \mathrm{~mL} \mathrm{Hg}\left(\mathrm{NO}_{3}\right)_{2}$ standard $1000 \mathrm{ppm}$ solution. The initial $\mathrm{Hg}$ concentration is $2 \mathrm{mg} / 100 \mathrm{~mL}$.

8. $99 \mathrm{mI}$ deionized water, $0.02 \mathrm{~g} \mathrm{NaHSO}_{3}, 1.0 \mathrm{~mL} \mathrm{Hg}\left(\mathrm{NO}_{3}\right)_{2}$ standard $1000 \mathrm{ppm}$ solution. The initial $\mathrm{Hg}$ concentration is $1 \mathrm{mg} / 100 \mathrm{~mL}$.

9. $99 \mathrm{~mL}$ deionized water, $0.5 \mathrm{~g} \mathrm{NaHSO}_{3}, 2.0 \mathrm{~mL} \mathrm{Hg}\left(\mathrm{NO}_{3}\right)_{2}$ standard $1000 \mathrm{ppm}$ solution. The initial $\mathrm{Hg}$ concentration is $2 \mathrm{mg} / 100 \mathrm{~mL}$.

10. $2.0 \mathrm{~mL} \mathrm{Hg}\left(\mathrm{NO}_{3}\right)_{2}$ standard $1000 \mathrm{ppm}$ solution, $0.5 \mathrm{~g} \mathrm{NaHSO}, 0.3 \mathrm{~g}$ $\mathrm{NaNO}_{3}$ in $100 \mathrm{~mL}$ deionized water. The initial $\mathrm{Hg}$ concentration is $2 \mathrm{mg} / 100 \mathrm{~mL}$. 
M. A. EBRA $-8-$

DPST $-86-333$

March 13,1986

\section{$\mathrm{NH}_{3}$}

11. $99 \mathrm{~mL} 0.0083 \mathrm{M} \mathrm{NH}_{4} \mathrm{OH}, 1.0 \mathrm{~mL} \mathrm{Hg}\left(\mathrm{NO}_{3}\right)_{2}$ standard $1000 \mathrm{ppm}$ solution. The initial $\mathrm{Hg}$ concentration is $1 \mathrm{mg} / 100 \mathrm{~mL}$.

12. $94 \mathrm{~mL} 0.0083 \mathrm{M} \mathrm{NH}_{4} \mathrm{OH}, 1.0 \mathrm{~mL} \mathrm{Hg}\left(\mathrm{NO}_{3}\right)_{2}$ standard $1000 \mathrm{ppm}$ solution, $5.0 \mathrm{~mL} 15 \mathrm{M} \mathrm{NH}_{4} \mathrm{OH}$. The initial $\mathrm{Hg}$ concentration is 1 $\mathrm{mg} / 100 \mathrm{~mL}$.

\section{$\mathrm{SnCl}_{2}$}

13. $94 \mathrm{~mL}$ deionized water, $5 \mathrm{~mL} 11 \% \mathrm{SnCl}_{2}, 1.0 \mathrm{~mL} \mathrm{Hg}\left(\mathrm{NO}_{3}\right)_{2}$ standard $1000 \mathrm{ppm}$ solution. The initial $\mathrm{Hg}$ concentration is $1 \mathrm{mg} / 100 \mathrm{~mL}$.

14. $94 \mathrm{~mL}$ deionized water, $5 \mathrm{~mL} 11 \% \mathrm{SnCl}_{2}, 1.0 \mathrm{~mL} \mathrm{Hg}\left(\mathrm{NO}_{3}\right)_{2}$ standard $1000 \mathrm{ppm}$ solution, glass wool baffle. The initial Hg concentration is $1 \mathrm{mg} / 100 \mathrm{~mL}$. 
TABLE 1

Hg VOLATILITY

\section{FEED SOIUTION \# $a$}

1. Blank, $1 \mathrm{mg} \mathrm{Hg}^{2+}$

2. Blank, $\mathrm{KMnO}_{4}, \mathrm{lmg} \mathrm{Hg}^{2+}$

3. Blank, Hg metal

4. dil $\mathrm{NaESO}_{3}, 1 \mathrm{mg} \mathrm{Hg}^{2+}$

5. dil $\mathrm{NaFSO}_{3}, 1 \mathrm{mg} \mathrm{Hg}^{2+}$, $0.15 \mathrm{M} \mathrm{NaNO}$

6. dil $\mathrm{NaZSO}_{3}, 1 \mathrm{mg} \mathrm{Hg}{ }^{2+}$, glass wool

7. dil $\mathrm{NaHSO}_{3}, 2 \mathrm{mg} \mathrm{Hg}{ }^{2+}$

8. $\mathrm{xS} \mathrm{NaHSO}_{3}, 1 \mathrm{mg} \mathrm{Hg}{ }^{2+}$

9. $\mathrm{xS} \mathrm{NaHSO}_{3}, 2 \mathrm{mg} \mathrm{Hg}{ }^{2+}$

10.xs $\mathrm{NaHSO}_{3}, 2 \mathrm{mg} \mathrm{Hg}{ }^{2+}, \mathrm{NaNO}_{3}$

11. dil $\mathrm{NE}_{4} \mathrm{OH}, 1 \mathrm{mg} \mathrm{Hg}{ }^{2+}$

12. con $\mathrm{NE}_{4} \mathrm{OH}, 1 \mathrm{mg} \mathrm{Hg}^{2+}$

13. $\mathrm{SnCl}_{2}, 1 \mathrm{mg} \mathrm{Hg}^{2+}$

14. $\mathrm{SnCl}_{2}, 1 \mathrm{mg} \mathrm{Hg}^{2+}$, glass wool

\section{MERCURY IN CONCENTRATE}

$.941 \mathrm{mg}$

$.980 \mathrm{mg}$

$3.15 \mathrm{E}-3 \mathrm{mg}$

1. $98 \mathrm{E}-3 \mathrm{mg}$

$1.0 \mathrm{E}-2 \mathrm{mg}$

$3.87 \mathrm{E}-3 \mathrm{mg}$

$.047 \mathrm{mg}$

$5.70 \mathrm{E}-2 \mathrm{mg}$

$.050 \mathrm{mg}$

$3,90 \mathrm{E}-2 \mathrm{mg}$

$.039 \mathrm{mg}$

$2.52 \mathrm{E}-2 \mathrm{mg}$

$.066 \mathrm{mg}$

$9.90 \mathrm{E}-3 \mathrm{mg}$

none detected

8. $55 \mathrm{E}-2 \mathrm{mg}$

$.310 \mathrm{mg}$

3. $33 \mathrm{E}-2 \mathrm{mg}$

$.960 \mathrm{mg}$

$2.12 \mathrm{E}-2 \mathrm{mg}$

$.756 \mathrm{mg}$

$7.83 \mathrm{E}-3 \mathrm{mg}$

$.916 \mathrm{mg}$

$1.21 \mathrm{E}-2 \mathrm{mg}$

none detected

$1.67 \mathrm{E}-2 \mathrm{mg}$

none detected

a. See Appendix 1 for complete solution compositions

b. In a total volume of $10 \mathrm{~mL}$; concentrations are an average for 3 or more runs

c. In a total volume of $90 \mathrm{~mL}$; concentrations are an average for 3 or more runs 
FIGURE 1

EXPERIMENTAL APPARATUS

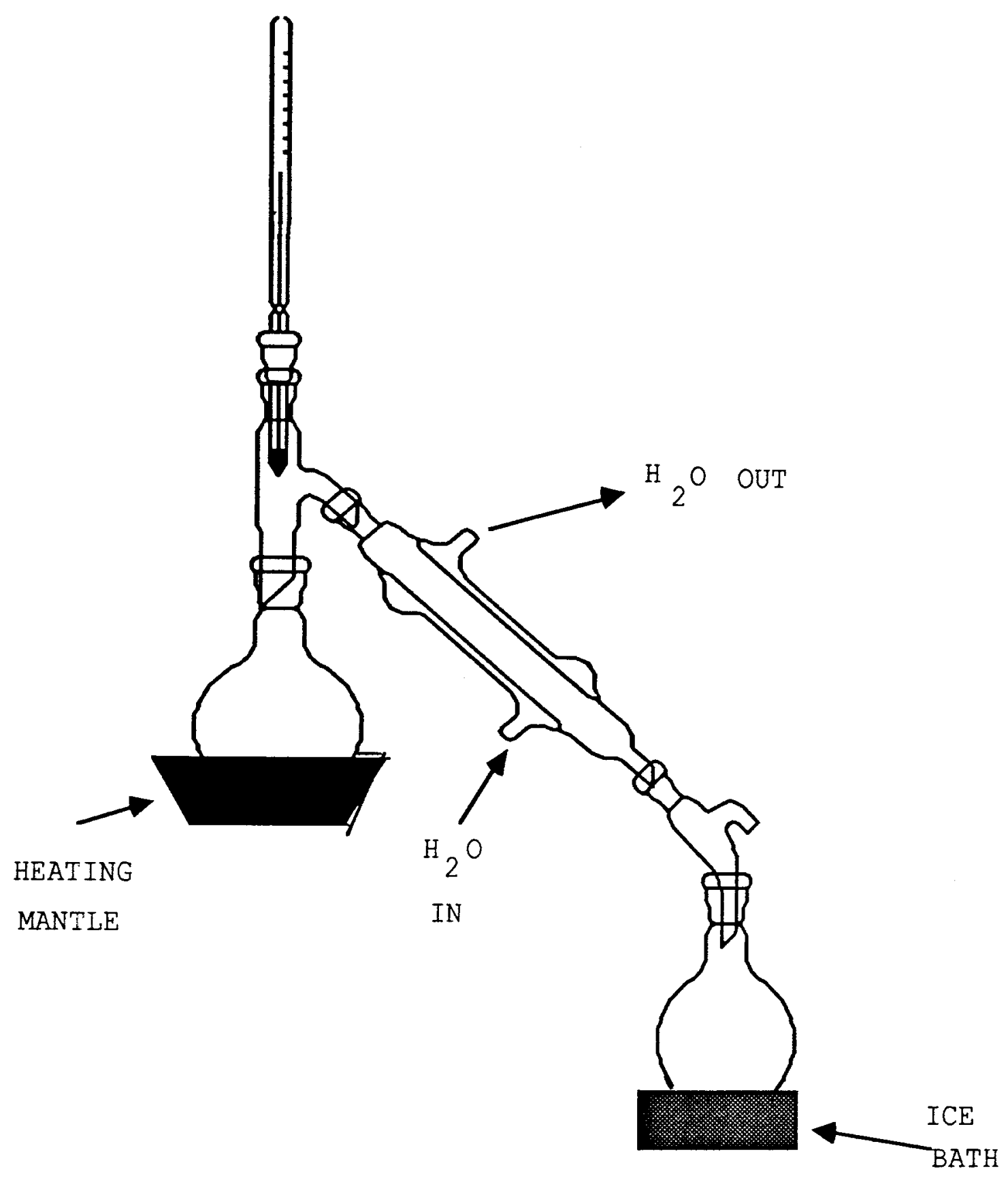

